\title{
Sensing of Soot Oxidation by Using Combustion-Type Sensor with Ag-Supported Catalyst
}

\author{
Hongcheng Ruan, Maiko Nishibori, ${ }^{*}$ Tsutomu Itou, \\ Yoshihiko Sadaoka, ${ }^{1}$ and Yasutake Teraoka \\ Department of Molecular and Material Sciences, Interdisciplinary Graduate School of Engineering Sciences, \\ Kyushu University, Kasuga, Fukuoka 816-8580, Japan \\ ${ }^{1}$ Department of Materials Science and Biotechnology, Graduate School of Science and Engineering, \\ Ehime University, 3 Bunkyo-cho, Matsuyama, Ehime 790-8577, Japan
}

(Received June 10, 2016; accepted August 3, 2016)

Keywords: particulate matter, oxidation, catalyst, combustion-type sensor

Soot-sensing properties of the combustion-type sensor coated with Ag-supported catalysts $\left(\mathrm{Ag} / \mathrm{TiO}_{2}, \mathrm{Ag} / \alpha-\mathrm{Al}_{2} \mathrm{O}_{3}\right.$, and $\left.\mathrm{Ag} / \mathrm{CeO}_{2}\right)$ were investigated. The catalyst with a high carbon black (CB) oxidation activity in the tight contact (TC) mode had a high response speed, although the response speed had no relationship with the $\mathrm{CB}$ oxidation activity in the loose contact (LC) mode. Moreover, the difference in $\mathrm{CB}$ oxidation activities between TC and LC modes was consistent with the difference in response speed between $V_{10}$ and $V_{50}$, where $V_{10}$ and $V_{50}$ indicate the response speed of the $\mathrm{CB}$ oxidation at 10 and $50 \%$ of total output voltage. The catalyst with high intrinsic $\mathrm{CB}$ combustion activity improves the response property at initial combustion. On the other hand, the catalyst with the $\mathrm{CB}$ combustion activity, which does not depend on the contact state between the $\mathrm{CB}$ and the catalyst, improves the response property at later combustion.

\section{Introduction}

Particulate matter (PM), which mainly consists of soot and soluble organic fraction (SOF) from diesel engines, is one of the main pollutants causing the PM2.5 problem, along with other serious environmental and health problems. ${ }^{(1-3)}$ Generally, improving fuel quality, boosting engine performance, and developing diesel exhaust after-treatment systems are the main ways of reducing PM emissions from diesel vehicles. Research on diesel exhaust after-treatment is a promising solution. The catalysed diesel particulate filter (C-DPF) is commonly regarded as the most effective technology for reducing PM emissions from diesel engines, where the PM is trapped and oxidized using a catalyst at low temperatures. ${ }^{(4-6)}$ Therefore, to guarantee the efficient and stable operation of a diesel engine system with C-DPF after-treatment, on-board PM monitoring technology is required. ${ }^{(3,7,8)}$

For this reason, several soot detection technologies have been proposed by researchers in the last few decades. Potentiometric and amperometric soot sensors based on an oxide ion conductor (zirconia) and electrical insulator were proposed by Vogel and colleagues ${ }^{(8,9)}$ and Moss and colleagues, ${ }^{(10-12)}$ and these can be used for in situ measurements of soot concentration. Sensors based on the

"Corresponding author: e-mail: nishibori.maiko.511@m.kyushu-u.ac.jp 
electromagnetic wave method, which includes radio-frequency $(\mathrm{RF})^{(13,14)}$ and optical waves in terms of changing the light transmission, scattering or extinction, have also been used to monitor PM concentration. ${ }^{(15-18)}$ In addition, a series of PM sensors dependent on polarization resistance resulting from a four-electron electrochemical reaction $\left(\mathrm{C}+\mathrm{H}_{2} \mathrm{O} \rightarrow \mathrm{CO}_{2}+4 \mathrm{H}^{+}+4 \mathrm{e}^{-}\right)$by utilizing a solid electrolyte as well as an electrocatalyst were proposed by Hibino and colleagues. ${ }^{(7,19-21)}$

$\mathrm{Ag}$ is well known as an efficient partial oxidation catalyst. For instance, Ag has been used industrially for the epoxidation of ethylene $e^{(22,23)}$ and the oxdehydrogenation of methanol to formaldehyde. ${ }^{(24-26)}$ In addition, $\mathrm{Ag}$ is well-used for $\mathrm{NO}_{\mathrm{x}}$ abatement, ${ }^{(27,28)}$ and the oxidation of ammonia, ${ }^{(29)}$ methane, ${ }^{(30)}$ carbon monoxide, ${ }^{(31)}$ organic volatile compounds. ${ }^{(32)} \mathrm{Ag}$ with support materials such as $\mathrm{ZrO}_{2}, \mathrm{TiO}_{2}, \mathrm{Al}_{2} \mathrm{O}_{3}$ and $\mathrm{CeO}_{2}$ also showed remarkable performance for diesel soot oxidation. ${ }^{(33-36)}$

In this study, we evaluate the soot oxidation activities of $\mathrm{Ag}$-supported catalysts $(\mathrm{Ag} / \mathrm{TiO}, \mathrm{Ag} /$ $\alpha-\mathrm{Al}_{2} \mathrm{O}_{3}$, and $\mathrm{Ag} / \mathrm{CeO}_{2}$ ) and discuss the soot sensing properties of the catalytic combustion-type sensor, which converts oxidation heat into an electric signal, with these catalysts. Additionally, we evaluate the relationship between the sensing properties and the soot oxidation activities of the catalysts.

\section{Experimental Procedure}

\subsection{Catalysts for soot oxidation}

$\mathrm{TiO}_{2}$ [JRC-TiO-4(2), Catalysis Society of Japan], $\alpha-\mathrm{Al}_{2} \mathrm{O}_{3}$ (Taimei Chemicals), and $\mathrm{CeO}_{2}$ (JRCCEO-2, Catalysis Society of Japan) were used as the catalyst supports. To change the particle size, $\mathrm{CeO}_{2}$ was calcined at 500 and $1300{ }^{\circ} \mathrm{C}$. Ag-loaded catalysts were prepared by ordinary impregnation of the catalyst support material with an aqueous solution of silver nitrate $\left[\mathrm{AgNO}_{3}(\mathrm{Kishida}\right.$ Chemical)]. The Ag content in the catalyst was fixed at $4.5 \mathrm{wt} \%$ on the basis of our previous research. ${ }^{(36)}$ The suspended solutions were evaporated to dryness under stirring at $350{ }^{\circ} \mathrm{C}$ and then baked at $350{ }^{\circ} \mathrm{C}$ for $2 \mathrm{~h}$, followed by calcination at $500^{\circ} \mathrm{C}$ for $5 \mathrm{~h}$ in air.

The Brunauer, Emmett, and Teller (BET) specific surface areas of the catalysts were measured by nitrogen adsorption at $77 \mathrm{~K}$ (BELSORP-mini gas adsorption analyzer, BEL Japan, Inc.). Thermogravimetry (TG) and differential thermal analysis (DTA) measurements (TG/DTA 7300, HITACHI) were carried out to evaluate the soot oxidation activity of the catalysts at a heating rate of $10{ }^{\circ} \mathrm{C} \mathrm{min}{ }^{-1}$ from 30 to $800{ }^{\circ} \mathrm{C}$ in synthetic air $\left(21\right.$ vol. $\% \mathrm{O}_{2}$ and 79 vol.\% $\left.\mathrm{N}_{2}, 100 \mathrm{ml} \mathrm{min}^{-1}\right)$ after the pre-heat treatment at $120^{\circ} \mathrm{C}$ for $2 \mathrm{~h}$. In this study, commercially available carbon black (CB, Sigma-Aldrich), which has a particle size of $5 \mu \mathrm{m}$, was used as a substitute for soot. All the catalysts and $\mathrm{CB}$ were mixed by grinding together in a mortar with pestle and spatula for $10 \mathrm{~min}$, denoted as tight contact (TC) mode and loose contact (LC) mode, respectively.

\subsection{Fabrication and evaluation of sensor}

The sensor element and fabrication of the sensing device are shown in Fig. 1. Sensor elements, a combination of a Pt coil and $\gamma-\mathrm{Al}_{2} \mathrm{O}_{3}$ bead, were coated with a slurry of $\mathrm{Ag} / \mathrm{TiO} \mathrm{O}_{2}, \mathrm{Ag} / \alpha-\mathrm{Al}_{2} \mathrm{O}_{3}$, and $\mathrm{Ag} / \mathrm{CeO}_{2}$ catalysts, respectively. They were then heated at $600{ }^{\circ} \mathrm{C}$ for $2 \mathrm{~h}$ in air by using an internal Pt heater of the sensor element to remove the binder resin. After that, the CB slurry was coated on the catalyst-coated sensor element, followed by heating at $200{ }^{\circ} \mathrm{C}$ for $2 \mathrm{~h}$ in air. The catalyst 


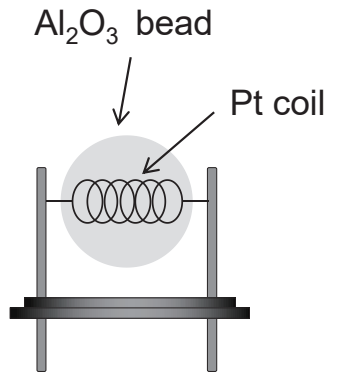

(a)

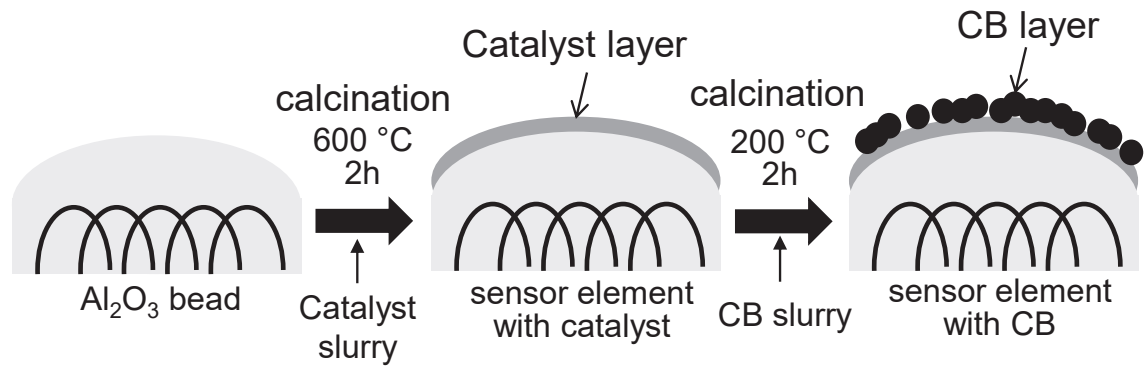

(b)

Fig. 1. Schematic of (a) sensor element and (b) fabrication of sensing device.

slurry was prepared by mixing catalysts and terpineol $\left(\mathrm{C}_{10} \mathrm{H}_{18} \mathrm{O}\right.$, Wako $)$ at a weight ratio of 9:1 for 3 min using a mixer (AR-100, Thinky) for $3 \mathrm{~min}$. On the other hand, the $\mathrm{CB}$ slurry was prepared by mixing $\mathrm{CB}$ and terpineol at a weight ratio of 12:1.

The sensing principle and measurement system used in this study were the same as those described in previous research. ${ }^{(3)}$ A Wheatstone bridge circuit, which includes a sensor element coated with the catalyst and a reference element without the catalyst, was employed. The temperature dependence of output voltage for $\mathrm{CB}$ oxidation was measured from 50 to $600{ }^{\circ} \mathrm{C}$ at intervals of $50{ }^{\circ} \mathrm{C}$ in synthetic air at a gas flow rate of $50 \mathrm{ml} \mathrm{min}{ }^{-1}$. The temperature of the sensor element was controlled and kept constant for $3 \mathrm{~min}$ at each measurement temperature by the $\mathrm{Pt}$ heater. On the other hand, the response property was investigated at a constant temperature of 600 ${ }^{\circ} \mathrm{C}$ by changing the gas from $\mathrm{N}_{2}$ to air.

\section{Results and Discussion}

\section{1 $\mathrm{CB}$ oxidation activity of $\mathrm{Ag} / \mathrm{TiO}_{2}, \mathrm{Ag} / \alpha-\mathrm{Al}_{2} \mathrm{O}_{3}$, and $\mathrm{Ag} / \mathrm{CeO} \mathrm{O}_{2}$ catalysts}

The TG-DTA curves for $\mathrm{CB}$ oxidation of $\mathrm{Ag} / \mathrm{TiO}_{2}, \mathrm{Ag} / \alpha-\mathrm{Al}_{2} \mathrm{O}_{3}$, and $\mathrm{Ag} / \mathrm{CeO}_{2}$ catalysts in $\mathrm{TC}$ and LC modes are shown in Fig. 2. Table 1 shows the specific surface area and CB oxidation activities in TC and LC modes. $T_{\mathrm{ig}}$ and $T_{\max }$ indicate the starting temperature of weight loss in the TG curve and the peak temperature of the DTA curve, respectively.

In the $\mathrm{TC}$ mode, the $\mathrm{Ag} / \mathrm{TiO}_{2}$ catalyst showed higher $\mathrm{CB}$ oxidation activity, which means lower oxidation temperatures of $T_{\text {ig }}$ and $T_{\max }$, than the $\mathrm{Ag} / \alpha-\mathrm{Al}_{2} \mathrm{O}_{3}$ and $\mathrm{Ag} / \mathrm{CeO} \mathrm{C}_{2}$ catalysts. Although both $\mathrm{Ag} / \alpha-\mathrm{Al}_{2} \mathrm{O}_{3}$ and $\mathrm{Ag} / \mathrm{CeO}_{2}$ catalysts showed the same $T_{\text {ig }}, T_{\text {max }}$ with the $\mathrm{Ag} / \alpha-\mathrm{Al}_{2} \mathrm{O}_{3}$ catalyst was lower than that with the $\mathrm{Ag} / \mathrm{CeO}_{2}$ catalyst and had a sharp DTA peak, which means quick combustion of CB. In the $\mathrm{LC}$ mode, both $\mathrm{Ag} / \alpha-\mathrm{Al}_{2} \mathrm{O}_{3}$ and $\mathrm{Ag} / \mathrm{CeO}_{2}$ catalysts showed the same $T_{\text {ig }}$ and $T_{\text {max }}$, and this suggests that the $\mathrm{CB}$ oxidation activities of these catalysts are not different in the state in which $\mathrm{CB}$ and the catalysts contacted weakly. Furthermore, the $\mathrm{CB}$ oxidation activity of the $\mathrm{Ag} / \mathrm{TiO}_{2}$ catalyst was low and $T_{\max }$ was higher than those of the $\mathrm{Ag} / \alpha-\mathrm{Al}_{2} \mathrm{O}_{3}$ and $\mathrm{Ag} / \mathrm{CeO}_{2}$ catalysts.

The $\mathrm{Ag} / \mathrm{TiO}_{2}$ catalyst has an intrinsically high activity for $\mathrm{CB}$ oxidation and showed a large difference in catalytic activity between the TC and LC modes. On the other hand, the $\mathrm{Ag} / \mathrm{CeO}$ catalyst is different from the other two catalysts and showed similar $\mathrm{CB}$ oxidation activity between the TC and LC modes. 


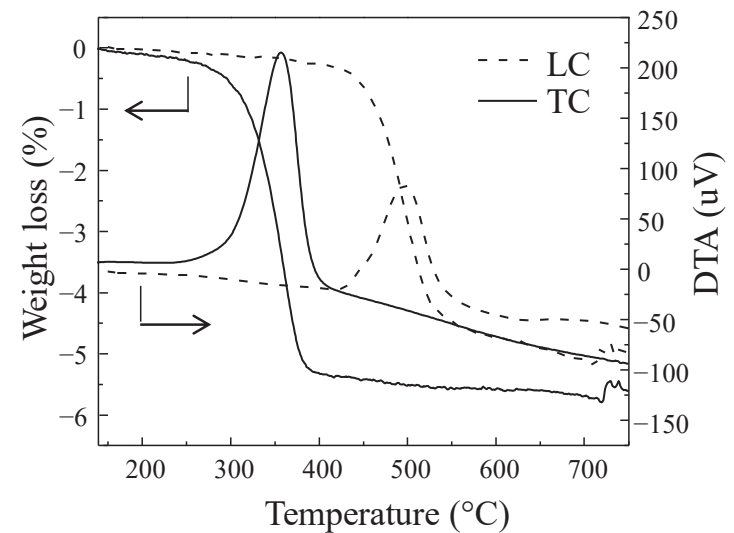

(a)

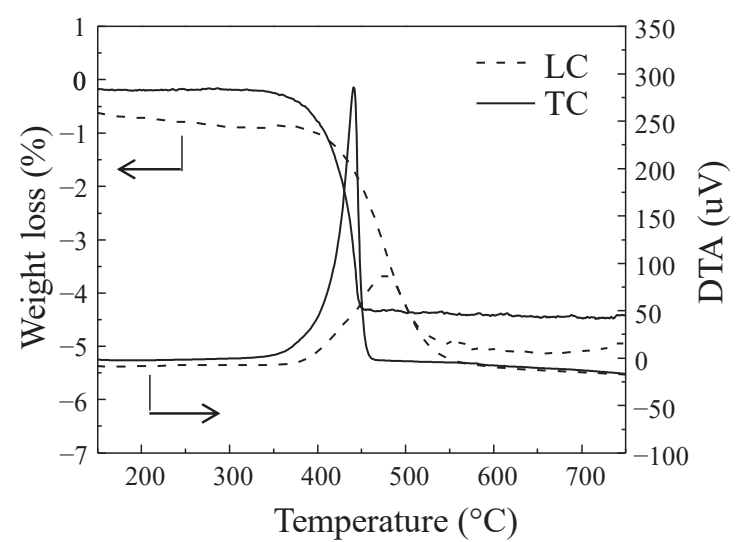

(b)

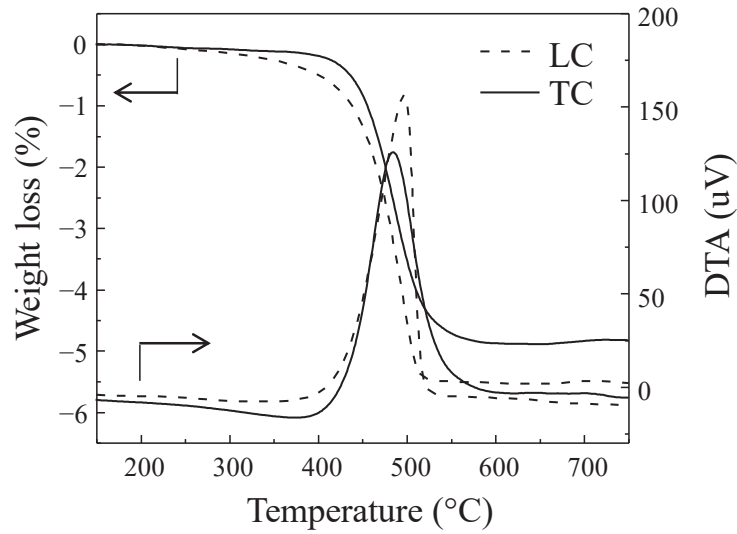

(c)

Fig. 2. TG-DTA curves for $\mathrm{CB}$ oxidation with (a) $\mathrm{Ag} / \mathrm{TiO}$, (b) $\mathrm{Ag} / \alpha-\mathrm{Al}_{2} \mathrm{O}_{3}$, and (c) $\mathrm{Ag} / \mathrm{CeO}_{2}$ catalysts in $\mathrm{TC}$ and LC modes.

Table 1

Specific surface area and catalytic performances for CB combustion in both TC and LC modes.

\begin{tabular}{|c|c|c|c|c|c|c|}
\hline \multirow{3}{*}{ Catalyst } & \multirow{3}{*}{$S_{\mathrm{BET}}\left(\mathrm{m}^{2} \mathrm{~g}^{-1}\right)^{\mathrm{a}}$} & \multicolumn{5}{|c|}{$\mathrm{CB}$ oxidation performance $\left({ }^{\circ} \mathrm{C}\right)^{\mathrm{b}}$} \\
\hline & & \multicolumn{2}{|c|}{ TC mode } & \multicolumn{2}{|c|}{ LC mode } & \multirow{2}{*}{$\Delta T_{\max }$} \\
\hline & & $T_{\text {ig }}$ & $T_{\max }$ & $T_{\mathrm{ig}}$ & $T_{\max }$ & \\
\hline $\mathrm{Ag} / \mathrm{TiO}_{2}$ & 11.2 & 268 & 357 & 376 & 497 & 140 \\
\hline $\mathrm{Ag} / \alpha-\mathrm{Al}_{2} \mathrm{O}_{3}$ & 5.6 & 340 & 442 & 404 & 480 & 38 \\
\hline $\mathrm{Ag} / \mathrm{CeO}_{2}$ & 0.5 & 346 & 492 & 405 & 484 & 8 \\
\hline
\end{tabular}

${ }^{a}$ Specific surface area.

${ }^{\mathrm{b}} T_{\text {ig }}$ starting temperature of weight loss in TG curve; $T_{\max }$ peak temperature of DTA curves; $\Delta T_{\max }$ difference of $\Delta T_{\max }$ between TC and LC modes.

\subsection{Temperature dependence of output voltage for CB oxidation using sensor elements}

Figure 3 shows the temperature dependence of output voltage for $\mathrm{CB}$ oxidation using the sensor elements coated with $\mathrm{Ag} / \mathrm{TiO}{ }_{2}, \mathrm{Ag} / \alpha-\mathrm{Al}_{2} \mathrm{O}_{3}$, and $\mathrm{Ag} / \mathrm{CeO}_{2}$ catalysts. Here, the increase in output voltage corresponds to $\mathrm{CB}$ combustion with different catalysts. For the sensor element with the $\mathrm{Ag} / \mathrm{TiO}_{2}$ catalyst [Fig. 3(a)], the output voltage began to increase from $300{ }^{\circ} \mathrm{C}$ and then increased 


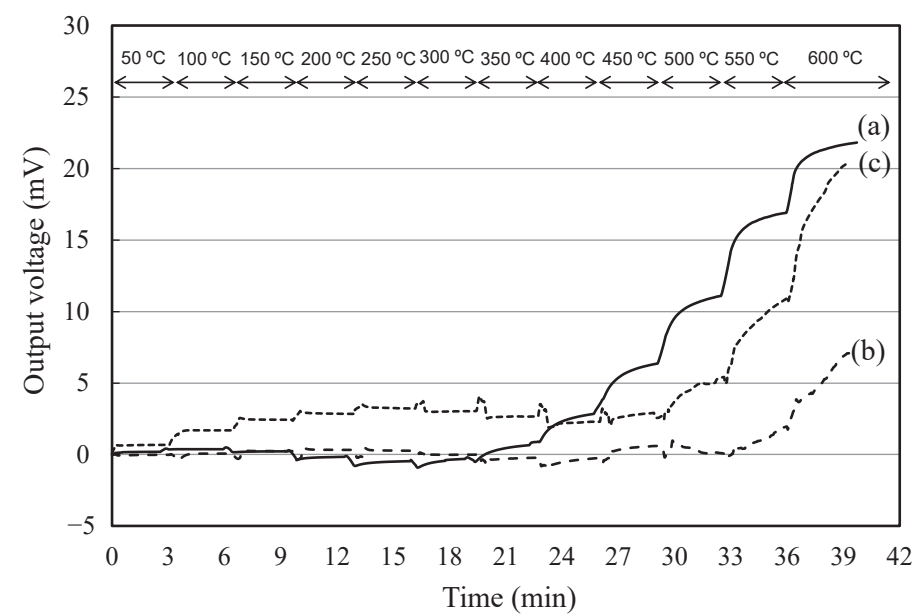

Fig. 3. Temperature dependence of output voltage for $\mathrm{CB}$ oxidation using sensor elements with (a) $\mathrm{Ag} / \mathrm{TiO}{ }_{2}$, (b) $\mathrm{Ag} / \alpha-\mathrm{Al}_{2} \mathrm{O}_{3}$, and (c) $\mathrm{Ag} / \mathrm{CeO}_{2}$ catalysts.

rapidly with increasing temperature owing to the $\mathrm{CB}$ oxidation reaction with the increase in $\mathrm{CB}$ combustion heat. Moreover, for the sensor elements with $\mathrm{Ag} / \alpha-\mathrm{Al}_{2} \mathrm{O}_{3}$ [Fig. 3(b)] and $\mathrm{Ag} / \mathrm{CeO}_{2}[$ Fig. $3(\mathrm{c})$ ], the output voltage began to increase from about 450 and $400{ }^{\circ} \mathrm{C}$, respectively.

The increase in the output voltage of the sensor elements with $\mathrm{Ag} / \mathrm{TiO} \mathrm{O}_{2}, \mathrm{Ag} / \mathrm{CeO}_{2}$, and $\mathrm{Ag} /$ $\alpha-\mathrm{Al}_{2} \mathrm{O}_{3}$ catalysts under constant temperature, $\Delta V$, which was estimated from Fig. 3 , is shown in Fig. 4(a) as a function of temperature. The $\Delta V$ corresponds to the combustion heat of $\mathrm{CB}$, which indicates the amount of combusted $\mathrm{CB}$ on the element. The $\Delta V$ of the sensor element with the $\mathrm{Ag} /$ $\mathrm{TiO}_{2}$ catalyst began to increase at $300{ }^{\circ} \mathrm{C}$ and increased rapidly at over $400{ }^{\circ} \mathrm{C}$ until most of the CB was burned off. At $600{ }^{\circ} \mathrm{C}$, the $\Delta V$ of the sensor element with the $\mathrm{Ag} / \mathrm{TiO}_{2}$ catalyst decreased because there was little residual $\mathrm{CB}$. In these cases, the contact condition between the catalyst layer and the $\mathrm{CB}$ is indicated by the schematic in Fig. 4(b). First, some CB that had a tight contact with the catalyst (such as the TC mode) burned between 300 and $400{ }^{\circ} \mathrm{C}$, as shown in Fig. 4(b-A). At over $400{ }^{\circ} \mathrm{C}$, the $\mathrm{CB}$ that had a loose contact with the catalyst (such as the LC mode) burned, as shown in Fig. 4(b-B). Then, at $600{ }^{\circ} \mathrm{C}$, a small amount of residual $\mathrm{CB}$, which had hardly any contact with the catalyst (much looser than the LC mode), burned [Fig. 4(b-C)].

The $\Delta V$ of the sensor element with the $\mathrm{Ag} / \mathrm{CeO}_{2}$ catalyst began to increase at $400{ }^{\circ} \mathrm{C}$ and $\mathrm{kept}$ increasing rapidly until $600^{\circ} \mathrm{C}$. It is considered that $\mathrm{CB}$, which had a loose contact with the catalyst [Fig. 4(b-B)], burned immediately after the combustion of $\mathrm{CB}$, which had a tight contact with the catalyst [Fig. 4(b-A)]. On the other hand, the $\Delta V$ of the sensor element with the $\mathrm{Ag} / \alpha-\mathrm{Al}_{2} \mathrm{O}_{3}$ catalyst hardly changed at the temperature of 450 to $550{ }^{\circ} \mathrm{C}$ and increased rapidly at $600{ }^{\circ} \mathrm{C}$. It is considered that much of the $\mathrm{CB}$ on the sensor element burned at approximately $600{ }^{\circ} \mathrm{C}$, which is close to the temperature of the natural combustion, although a small amount of $\mathrm{CB}$, which had a tight contact with the catalyst [Fig. 4(b-A)], burned.

These results suggest that the contact state is different between the catalyst and the $\mathrm{CB}$, which can be measured according to different sensor signals (output voltage). Moreover, it is clear that the contact state between the catalyst and the $\mathrm{CB}$ has a large effect on the sensing performance. 


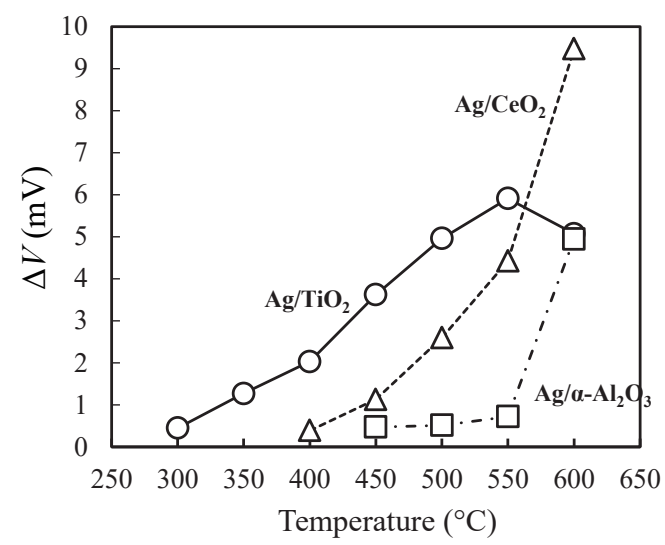

(a)

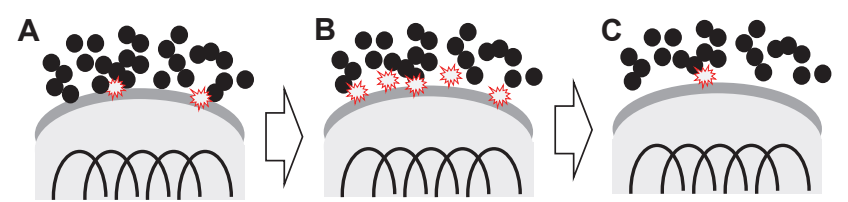

(b)

Fig. 4. (Color online) (a) Sensing performances $(\Delta V)$ for soot combustion with different catalysts at increasing temperature in air and (b) different contact modes of combustion condition.

\subsection{Sensing property in exchanged gas, $N_{2}$ to air, under constant temperature}

The sensing properties of the sensor elements with $\mathrm{Ag} / \mathrm{TiO}, \mathrm{Ag} / \mathrm{CeO}$, and $\mathrm{Ag} / \alpha-\mathrm{Al}_{2} \mathrm{O}_{3}$ catalysts under constant temperature are shown in Fig. 5. The sensor element coated with the catalyst and the $\mathrm{CB}$ was kept in $\mathrm{N}_{2}$ for $5 \mathrm{~min}$ at $600{ }^{\circ} \mathrm{C}$ and then the gas was changed to air at the same temperature. It is clear that almost all the $\mathrm{CB}$ coated with different catalysts had burned after changing $\mathrm{N}_{2}$ to air. Here, the peak output voltage after changing $\mathrm{N}_{2}$ to air is caused by the CB combustion in the TC mode, indicating that the combustion heat of $\mathrm{CB}$ conducted through the sensor element to the $\mathrm{Pt}$ coil. The increase in output voltage after that peak is caused by CB combustion in the LC mode and indicates the decrease in the amount of residual CB with high heat capacity because the combustion heat hardly conducts to the Pt coil.

In Fig. 5(a), $\mathrm{CB}$ coated on $\mathrm{Ag} / \mathrm{TiO}_{2}$ was oxidized suddenly after changing $\mathrm{N}_{2}$ to air, and the difference in output voltage $\left(\Delta V, \Delta V=V_{\text {air }}-V_{\mathrm{N}}, V_{\text {air }}\right.$ is the output voltage in air and $V_{\mathrm{N}}$ is the output voltage in $\mathrm{N}_{2}$ ) was about $10 \mathrm{mV}$ during the first $5 \mathrm{~min}$, and the contact condition between the catalyst and the $\mathrm{CB}$ was near the TC mode [Fig. 4(b-A)]. The output voltage continued to increase with time, and the contact condition between the catalyst and the CB is near the LC mode [Fig. 4(b$\mathrm{B})$ ]. The residual $\mathrm{CB}$ continued to be burned while the output voltage increased slightly until all the $\mathrm{CB}$ burned out. Figure 5(b) shows the sensing property of the sensor element coated with both $\mathrm{Ag}$ / $\alpha-\mathrm{Al}_{2} \mathrm{O}_{3}$ and $\mathrm{CB}$. The output voltage returned to the same level as in $\mathrm{N}_{2}$ following a sharp oxidation peak after changing $\mathrm{N}_{2}$ to air and then increased slowly until all the CB was consumed, thereby showing a fast combustion speed, because most of the $\mathrm{CB}$ was oxidized during the first $5 \mathrm{~min}$. The sensing property of the sensor element coated with both $\mathrm{Ag} / \mathrm{CeO}_{2}$ and $\mathrm{CB}$ is shown in Fig. 5(c), and its output voltage gradually increased without the peak after changing $\mathrm{N}_{2}$ to air, which was different from that of the other two sensors.

The difference in sensing properties among these sensor elements coated with different catalysts is mainly due to the different internal properties of the catalysts. To understand the relationship between the sensing properties and the oxidation performance of the $\mathrm{CB}$, we evaluated the response 


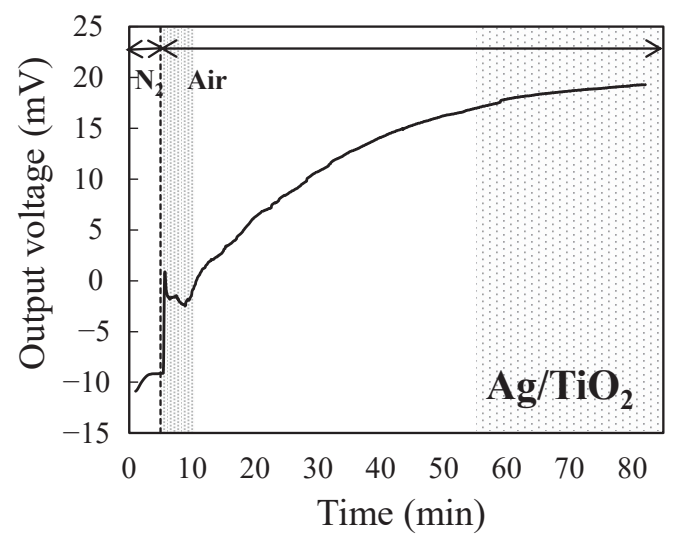

(a)

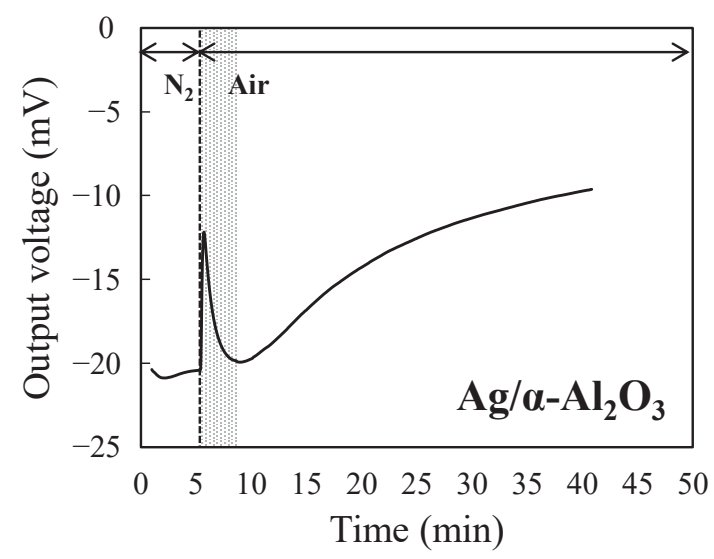

(b)

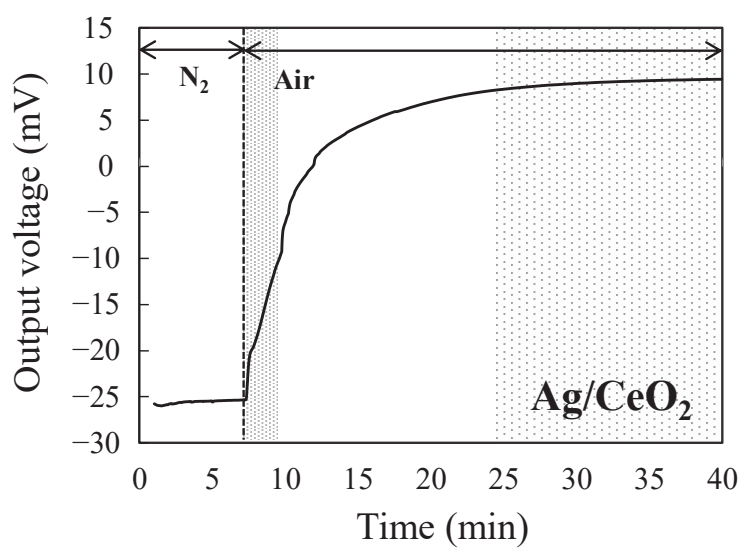

(c)

Fig. 5. Sensing performances for soot combustion with different catalysts at $600{ }^{\circ} \mathrm{C}$ for 5 min before changing $\mathrm{N}_{2}$ to air: (a) $\mathrm{Ag} / \mathrm{TiO}_{2}$, (b) $\mathrm{Ag} / \alpha-\mathrm{Al}_{2} \mathrm{O}_{3}$, and (c) $\mathrm{Ag} / \mathrm{CeO}_{2}$.

speed of the $\mathrm{CB}$ oxidation. The response speed of the $\mathrm{CB}$ oxidation at 10 and $50 \%$ of the total output voltage was denoted as $V_{10}$ and $V_{50}$, respectively, as shown in Fig. 6 . The total output voltage $\Delta V$ is the difference between the output voltage at which all the $\mathrm{CB}$ was oxidized and the output voltage in $\mathrm{N}_{2}$ before oxidation.

Figure 7 shows the comparison of the response speeds for $\mathrm{CB}$ oxidation estimated from the equation described above. The response speeds $V_{10}$ of $\mathrm{CB}$ oxidation were 50,34 , and $21 \mathrm{mV} \cdot \mathrm{min}^{-1}$ for sensor elements with $\mathrm{Ag} / \mathrm{TiO}_{2}, \mathrm{Ag} / \alpha-\mathrm{Al}_{2} \mathrm{O}_{3}$, and $\mathrm{Ag} / \mathrm{CeO}_{2}$ catalysts, respectively. The peak area of the output voltage after changing $\mathrm{N}_{2}$ to air corresponds to the amount of combustion heat $(\Delta H)$. The amplitude of the estimated $\Delta H$ from Fig. 6 became large in the order of the sensor elements with $\mathrm{Ag} / \mathrm{TiO}_{2}, \mathrm{Ag} / \alpha-\mathrm{Al}_{2} \mathrm{O}_{3}$, and $\mathrm{Ag} / \mathrm{CeO}_{2}$ catalysts. Therefore, this suggests that the catalyst with a high $\mathrm{CB}$ oxidation activity has a fast response speed at an early stage. On the other hand, the response speeds $V_{50}$ of $\mathrm{CB}$ oxidation were $1.6,0.7$, and $17.7 \mathrm{mV} \cdot \mathrm{min}^{-1}$ for sensor elements with $\mathrm{Ag}$ / $\mathrm{TiO}_{2}, \mathrm{Ag} / \alpha-\mathrm{Al}_{2} \mathrm{O}_{3}$, and $\mathrm{Ag} / \mathrm{CeO}_{2}$ catalysts, respectively. This suggests that the $V_{50}$ of $\mathrm{CB}$ oxidation has no relation with the oxidation heat. 


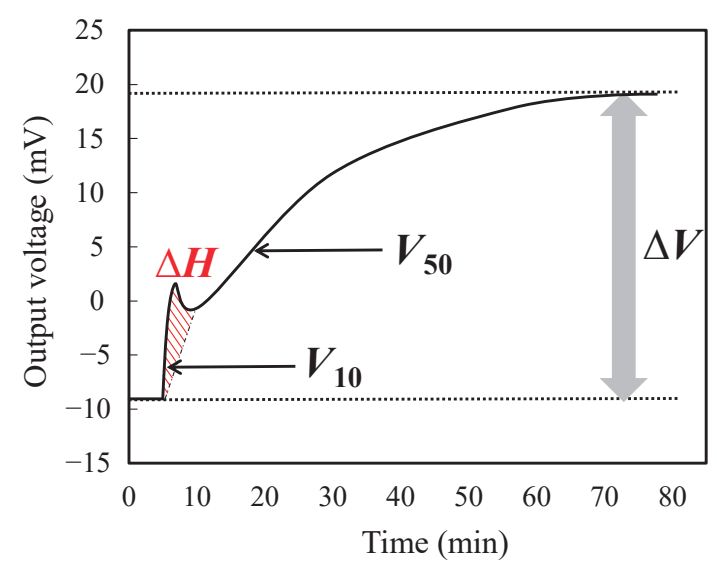

Fig. 6. (Color online) $V_{10}$ and $V_{50}$ of the total output voltage.

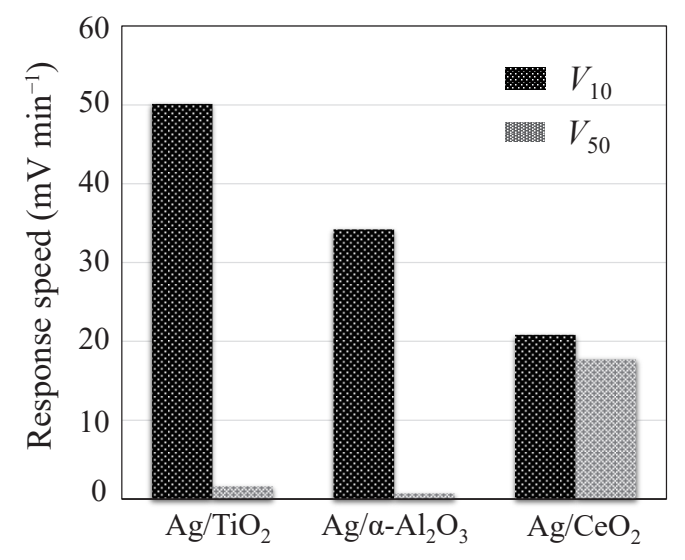

Fig. 7. Comparison of response speed $\left(V_{10}\right.$ and $\left.V_{50}\right)$ for $\mathrm{CB}$ sensing.

As shown in Table 1, it is clear that the catalyst with better catalytic activity in $T_{\max }$ in the TC mode had a higher response speed $V_{10}$ for $\mathrm{CB}$ oxidation. However, the $V_{50}$ for $\mathrm{CB}$ oxidation has no relationship with the catalytic activity in $T_{\max }$ in the LC mode. Moreover, although the response curve of the sensor element with the $\mathrm{Ag} / \mathrm{CeO}_{2}$ catalyst increased gradually without an obvious peak after changing the gas (from $\mathrm{N}_{2}$ to air), its $V_{50}$ was highest among the sensor elements with these catalysts.

In the case of the sensor element with the $\mathrm{Ag} / \mathrm{CeO}_{2}$ catalyst, the difference between $V_{10}$ and $V_{50}$ was very small compared with those of the sensor elements with $\mathrm{Ag} / \mathrm{TiO} \mathrm{O}_{2}$ and $\mathrm{Ag} / \alpha-\mathrm{Al}_{2} \mathrm{O}_{3}$ catalysts. In addition, the difference in the $\mathrm{CB}$ oxidation activities of the catalysts $\left(\Delta T_{\max }\right.$ in Table 1$)$ between the TC and LC modes was also consistent with the difference in the response speed between $V_{10}$ and $V_{50}\left(\Delta V_{50-10}\right)$. For example, the difference in the response speed, $\Delta V_{50-10}$, of the $\mathrm{CB}$ oxidation for the sensor element with the $\mathrm{Ag} / \mathrm{CeO}_{2}$ catalysts, which showed the smallest $\Delta T_{\max }\left(8{ }^{\circ} \mathrm{C}\right.$ in Table 1) for the $\mathrm{CB}$ combustion, was only $3.1 \mathrm{mV} \cdot \mathrm{min}^{-1}$, which was much smaller than 48.5 and $33.5 \mathrm{mV} \cdot \mathrm{min}^{-1}$ for the sensor elements with the $\mathrm{Ag} / \mathrm{TiO}_{2}$ and $\mathrm{Ag} / \mathrm{\alpha}-\mathrm{Al}_{2} \mathrm{O}_{3}$ catalysts, respectively.

These results suggest that the catalyst with the high intrinsic CB oxidation activity ( $T_{\max }$ in TC mode) improves the response property $\left(V_{10}\right)$ at an early stage. On the other hand, the catalyst that does not depend on the contact state (TC and LC modes) improves the response property of the $\mathrm{CB}$ oxidation at the later stage [Figs. 4(b-B) and 4(c-C)]. In this study, the best catalyst for the soot sensing is $\mathrm{Ag} / \mathrm{CeO}_{2}$, which showed almost the same response speed of $V_{10}$ and $V_{50}$. We suggest that the close response speed of $V_{10}$ and $V_{50}$ is most important in the real condition, regardless of the active species and the support materials. The contact state between the catalyst and the soot is quite loose under the practical condition. Therefore, the response speed of $V_{50}$ will become important for the catalyst used in the combustion-type PM sensor.

\section{Conclusion}

The soot-sensing properties of the combustion-type sensor coated with Ag-supported catalysts $\left(\mathrm{Ag} / \mathrm{TiO}_{2}, \mathrm{Ag} / \alpha-\mathrm{Al}_{2} \mathrm{O}_{3}\right.$, and $\left.\mathrm{Ag} / \mathrm{CeO}_{2}\right)$ were investigated. The catalyst with an intrinsically high $\mathrm{CB}$ oxidation activity had a high response speed although the response speed had no relationship 
with the $\mathrm{CB}$ oxidation activity, regardless of the contact state between the catalyst and the $\mathrm{CB}$. Moreover, the difference in $\mathrm{CB}$ oxidation activity between the TC and LC modes was consistent with the difference in the response speed between $V_{10}$ and $V_{50}$. The catalyst with high intrinsic CB combustion activity improves the response property at an initial combustion. On the other hand, the catalyst having $\mathrm{CB}$ combustion activity which does not depend on the contact state between the $\mathrm{CB}$ and the catalyst, improves the response property at later combustion.

In this study, we demonstrated not only the preliminary result of the detection for the soot oxidation under operation temperature but also indicated a catalyst design for soot oxidation. However, because most of our research in this work was focused on qualitative analysis, a more quantitative evaluation of the sensing property and measurements under real exhaust conditions isnecessary in the future.

\section{Acknowledgements}

This work was supported by the Adaptable and Seamless Technology Transfer Program through target driven R\&D from the Ministry of Education, Culture, Sports, Science and Technology, Japan.

\section{References}

J. C. Summers, S. Van Houtte, and D. Psaras: Appl. Catal., B 10 (1996) 139.

2 H. S. Rosenkranz: Mutat. Res. 367 (1996) 65.

3 C. B. Lim, H. Einaga, Y. Sadaoka, and Y. Teraoka: Sens. Actuators, B 160 (2011) 463.

4 M. Zheng, G. T. Reader, and J. G. Hawley: Energy Convers. Manage. 45 (2004) 883.

5 M. M. Maricq: J. Aerosol Sci. 38 (2007) 1079.

6 M. Ambrogio, G. Saracco, and V. Specchia: Chem. Eng. Sci. 56 (2001) 1613.

7 S. Teranishi, K. Kondo, A. Tsuge, and T. Hibino: Sens. Actuators, B 140 (2009) 170.

8 A. Vogel, V. Schüle, G. Baier, and A. Mahl: Sens. Actuators, B 18-19 (1994) 546.

9 V. Schüle, G. Baier, and A. Vogel: Sens. Actuators, B 15-16 (1993) 249.

10 G. Hagen, C. Feistkorn, S. Wiegartner, A. Heinrich, D. Bruggemann, and R. Moos: Sensors 10 (2010) 1589.

11 P. Bartscherer and R. Moos: J. Sens. Sens. Syst. 2 (2013) 95.

12 M. Feulner, G. Hagen, A. Müller, A. Schott, C. Zöllner, D. Brüggemann, and R. Moos: Sensors 15 (2015) 28796.

13 G. Fischerauer, M. Förster, and R. Moos: Meas. Sci. Technol. 21 (2010) 035108.

14 M. Feulner, G. Hagen, A. Piontkowski, A. Müller, G. Fischerauer, D. Brüggemann, and R. Moos: Top. Catal. $56(2013) 483$.

15 C. D. Litton: Fire Saf. J. 37 (2002) 409.

16 C. D. Litton: Fire Saf. J. 44 (2009) 387.

17 A. Keller, M. Rüegg, M. Forster, M. Loepfe, R. Pleisch, P. Nebiker, and H. Burtscher: Sens. Actuators, B 104 (2005) 1.

18 J. J. Murphy and C. R. Shaddix: Combust. Flame 143 (2005) 1.

19 Y. B. Shen, T. Takeuchi, S. Teranishi, and T. Hibino: Sens. Actuators, B 145 (2010) 708.

20 Y. B. Shen, T. Takeuchi, and T. Hibino: Sens. Actuators, B 153 (2011) 226.

21 Y. B. Shen, T. Harada, S. Teranishi, and T. Hibino: Sens. Actuators, B 162 (2012) 159.

22 Y. Shirashi and N. Toshima: J. Mol. Catal., A 141 (1999) 187.

23 J. P. A. Neeft, M. Makkee, and J. A. Moulijn: Fuel 77 (1998) 111.

24 A. N. Pestrvakov: Catal. Today 28 (1996) 239.

25 L. Kundakovic and M. Flytzani-Stephanopolus: Appl. Catal., A 183 (1999) 35.

26 A. Nagy and G. Mestl: Appl. Catal., A 188 (1999) 337.

27 P. W. Park and C. L. Boyer: Appl. Catal., B 59 (2005) 27.

28 R. Brosius, K. Arve, M. H. Groothaert, and J. A. Martens: J. Catal. 231 (2005) 344. 
29 L. Gang, B. G. Anderson, J. van Grondelle, R. A. van Santen, W. J. H. van Gennip, J. W. Niemantsverdriet, P. J. Kooyman, A. Knoester, and H. H. Brongersma: J. Catal. 206 (2002) 60.

30 S. Imamura, H. Yamada, and K. Utani: Appl. Catal., A 192 (2000) 221.

31 Z. Qu, M. Cheng, W. Huang, and X. Bao: J. Catal. 229 (2005) 446.

32 M. Luo, X. Yuan, and X. Zheng: Appl. Catal., A 175 (1998) 121.

33 E. Aneggi, J. Llorca, C. D. Leitenburg, G. Dolcetti, and A. Trovarelli: Appl. Catal., B 91 (2009) 489.

34 G. Corro, U. Pal, E. Ayala, and E. Vidal: Catal. Today 212 (2013) 63.

35 G. Corro, U. Pal, E. Ayala, E. Vidal, and E. Guilleminot: Catal. Today 56 (2013) 467.

36 T. Itoh, M. Nishibori, E. Einaga, and Y. Teraoka: Chem. Sens. 30, Supplement A (2014) 82. 